UDC 691:620.197

\title{
Long-term protection of building structures with sulfur-based nanoscale coatings
}

Authors:

Ismail A. Massalimov,

Professor of Bashkir State University (BashSU); Ufa, Bashkortostan Republic, Russia, ismail_mass@mail.ru;

Aleksandr E. Chuykin,

Associate Professor, Ufa State Petroleum Technological University (USPTU), Ufa, Bashkortostan Republic, Russia, an2100@yandex.ru;

Burhan I. Massalimov,

Graduate Student, Physics Institute. P.N. Lebedev, Russian Academy of Sciences; Moscow, Russia; burhan@mephist.ru;

Bulat S. Akhmetshin,

Assistant Professor, Bashkir State University Ufa, Bashkortostan Republic, Russia; akhbulat@mail.ru;

Farit H. Urakaev,

Senior Researcher, V.S. Sobolev Institute of Geology and Mineralogy of the Russian Academy Science; Russia, Novosibirsk, urakaev@igm.nsc.ru;

Muhambetkali M. Burkitbaev,

Vice Rector, Al-Farabi Kazakh National University; Al-Farabi, Almaty, Kazakhstan; mukhambetkali.Burkitbayev@kaznu.kz

Akhat G. Mustafin,

Head of Ufa Scientific Center, Ufa Bashkortostan Republic, Russia; agmustafin@gmail.com

Abstract: The problem of creating reliable protective coatings that increase the mechanical characteristics of concrete building structures (piles, bridges, ceiling arches, tunnels, chutes, culverts, wells, paving slabs and curbs, etc.) operated under the influence of atmospheric factors and groundwater is of great importance. Currently, the most effective way to prevent degradation of materials is the application of various kinds of protective compounds. That protects against various factors of aggressive natural and manmade impact and thus allows increasing the durability of buildings and structures by reducing the amount of water penetrating into the pores. To provide long-term protection of building materials, it is proposed to treat porous surfaces of building materials with a new sulfur-containing compound. The innovative developed impregnating composition is based on sulfur and it provides protection of building materials of different nature from weathering and corrosive media for a long time. Modification of the proposed composition can significantly improve performance and increase the service life of building materials.

Keywords: sulfur, polysulfide, nanoparticle, ceramics, concrete.

Acknowledgments: This work was supported by the PTsF of the Republic of Kazakhstan (contract No. 586 dated 04.04.2015) and a grant from the Russian Foundation for Assistance to the Development of Small Forms of Enterprises in the Scientific and Technical Sphere within the frames of the program in «Start 2015».

For citation: Massalimov I.A., Chuykin A.E., Massalimov B.I., Akhmetshin B. S., Urakaev F.H., Burkitbaev M.M., Mustafin A.G. Longterm protection of building structures with sulfur-based nanoscale coatings. Nanotehnologii $v$ stroitel'stve $=$ Nanotechnologies in Construction. 2019, Vol. 11, no. 3, pp. 276-287. DOI: 10.15828/2075-8545-2019-11-3-276-287.

Machine-readable information on CC-licenses (HTML-code) in metadata of the paper

$<$ a rel="license" href="http://creativecommons.org/licenses/by/4.0/" $><$ img alt="Creative Commons License" style="border-width:0" src="https://i.creativecommons.org/l/by/4.0/88x31.png" / ></a $><$ br $/><$ span xmlns:dct="http://purl.org/dc/terms/" href="http://purl.org/dc/dcmitype/Text" property="dct:title" rel="dct:type" $>$ Longterm protection of building structures with sulfur-based nanoscale coatings $</$ span $>$ by $<$ a $x m l n s: c c="$ http://creativecommons.org/ ns\#" href="Nanotehnologii v stroitel'stve = Nanotechnologies in Construction. 2019, Vol. 11, no. 3, pp. 276-287. DOI: 10.15828/2075-8545-2019-11-3-276-287" property="cc:attributionName" rel="cc:attributionURL" $>$ Massalimov I.A., Chuykin A.E., Massalimov B.I., Akhmetshin B. S., Urakaev F.H., Burkitbaev M.M., Mustafin A.G. $</ a>$ is licensed under a $<$ a rel="license" href="http://creativecommons.org/licenses/by/4.0/" $>$ Creative Commons Attribution 4.0 International License $</ a>$. $<$ br />Based on a work at <a xmlns:dct="http://purl.org/dc/terms/" href="http://nanobuild.ru/en_EN/nanobuild-3-2019/" rel="dct:source" $>$ http://nanobuild.ru/en_EN/nanobuild-3-2019/</a $>$. $<\mathrm{br} />$ Permissions beyond the scope of this license may be available at $<$ a xmlns:cc="http://creativecommons.org/ns\#" href="ismail_mass@mail. ru" rel="cc:morePermissions">ismail_mass@mail.ru</a>.

The paper has been received by editors: 02.04.2019.

The paper has been received by editors after peer-review: 23.04.2019.

The paper has been accepted for publication: 13.05.2019. 


\section{Долговременная защита строительных конструкций наноразмерными покрытиями на основе серы}

\section{Авторы:}

Масалимов Исмаил Александрович,

профессор Башкирского государственного университета (БашГУ); Уфа, Республика Башкортостан, Россия, ismail_mass@mail.ru;

\section{Чуйкин Александр Евгеньевич,}

доцент, Уфимский государственный нефтяной технический университет (УГНТУ), Уфа, Республика Башкортостан, Россия, an2100@yandex.ru;

\section{Массалимов Бурхан Исмаилович,}

аспирант Физического института им. П.Н. Лебедева, Российская академия наук; Москва, Россия; burhan@mephist.ru;

Ахметшин Булат Салаватович,

ассистент Башкирского государственного университета Уфа, Республика Башкортостан, Россия; akhbulat@mail.ru;

Уракаев Фарит Хисамутдинович,

старший научный сотрудник, В.С. Институт геологии и минералогии им. С.Л. Соболева РАН; Россия, Новосибирск, urakaev@igm.nsc.ru;

Буркитбаев Мухамбеткали Мырзабаевич,

проректор КазНУ им. Аль-Фараби; Аль-Фараби, Алматы, Казахстан; mukhambetkali.Burkitbayev@kaznu.kz

Мустафин Ахат Григорьевич,

руководитель Уфимского научного центра, Уфа, Республика Башкортостан, Россия, agmustafin@gmail.com

Резюме: Защитные материалы широко используются в промышленном и гражданском строительстве для увеличения срока службы строительных конструкций. Основная проблема их применения заключается в их недолговечности, особенно если они эксплуатируются в неблагоприятных условиях присутствия воды, знакопеременных температур и солнечной радиации.

Авторами статьи предлагается универсальный метод, позволяющий защищать все пористые неорганические строительные материалы составом на основе полисульфидов. Состав проникает на глубину более 1 см и при высыхании создает в поровом пространстве гидрофобное наноразмерное покрытие, состоящее из наночастиц серы. Покрытие придает материалам наряду с водоотталкивающими свойствами также стойкость по отношению к химическим веществам и патогенным грибам.

Ключевые слова: сера, полисульфид, наночастица, керамика, бетон.

Благодарности: Работа поддержана ПЦФ Республики Казахстан (договор № 586 от 07.04.2015 г.) и грантом Российского фонда содействия развитию малых форм предприятий в научно-технической сфере по программе «Старт 2015».

Для цитирования: Массалимов И.А., Чуйкин А.Е., Масалимов Б.И., Ахметшин Б.С., Уракаев Ф.Х., Буркитбаев М.М., Мустафин А.Г. Долговременная защита строительных конструкций с использованием наноразмерных покрытий на основе серы // Нанотехнологии в строительстве. - 2019. - Том 11, № 3. - С. 276-287. - DOI: 10.15828/2075-8545-2019-11-3-276-287.

Machine-readable information on CC-licenses (HTML-code) in metadata of the paper

$<$ a rel="license" href="http://creativecommons.org/licenses/by/4.0/"><img alt="Creative Commons License" style="border-width:0" src="https://i.creativecommons.org/l/by/4.0/88x31.png" / ></a $><$ br $/><$ span xmlns:dct="http://purl.org/dc/terms/" href="http://purl.org/dc/dcmitype/Text" property="dct:title" rel="dct:type" $>$ Longterm protection of building structures with sulfur-based nanoscale coatings $</$ span $>$ by $<$ a xmlns:cc="http://creativecommons.org/ ns\#" href="Nanotehnologii v stroitel'stve = Nanotechnologies in Construction. 2019, Vol. 11, no. 3, pp. 276-287. DOI: 10.15828/2075-8545-2019-11-3-276-287" property="cc:attributionName" rel="cc:attributionURL">Massalimov I.A., Chuykin A.E., Massalimov B.I., Akhmetshin B. S., Urakaev F.H., Burkitbaev M.M., Mustafin A.G. $</ a>$ is licensed under a $<$ a rel="license" href="http://creativecommons.org/licenses/by/4.0/" $>$ Creative Commons Attribution 4.0 International License $</ a>$. $<$ br />Based on a work at <a xmlns:dct="http://purl.org/dc/terms/" href="http://nanobuild.ru/en_EN/nanobuild-3-2019/" rel="dct:source" >http://nanobuild.ru/en_EN/nanobuild-3-2019/</a $>$. $<$ br $/>$ Permissions beyond the scope of this license may be available at $<$ a xmlns:cc="http://creativecommons.org/ns\#" href="ismail_mass@mail. ru" rel="cc:morePermissions">ismail_mass@mail.ru</a $>$.

Статья поступила в редакцию: 02.04.2019.

Статья поступила в редакцию после рецензирования: 23.04.2019.

Статья принята к публикации: 13.05.2019. 


\section{INTRODUCTION}

$\mathrm{T}$ he problem of creating reliable protective coatings that increase the mechanical characteristics of concrete building structures (piles, bridges, ceiling arches, tunnels, trays, culverts, wells, paving slabs and curbs, curbstones, etc.) operated under the influence of atmospheric factors and groundwater, is of great importance. Increased durability and reliability of road structures, operating under the influence of mechanical and atmospheric factors, is usually achieved by using various types of concrete modification [1] and the use of protective impregnating compositions [2, 3]. The main disadvantage of coatings is the fragility of the components the protective coatings consist of. In all buildings and structures there are structural elements exposed to intense moisture and groundwater effects: foundation blocks, pillows and slabs, piles; socle and subwindow sections of the walls, parapets, protruding elements of the facades (cornices, belts); cover plates; trays, wells, curbstones, paving slabs; arches, culverts, elements of bridges, etc. To protect them, it is insufficient just to form of a thin film of protective coating on the surface of the material, as it is necessary to use compositions that penetrate deeply into the material and prevent it from penetrating water with its constant impact. In these cases, various binders are applied (polymer, silicone, liquid glass, molten sulfur, etc.). Each of the listed materials has disadvantages. For example, organic and organosilicon compounds, despite their high efficiency at the beginning of their useful life, gradually undergo destruction and lose their protective functions. Thus, at present there is no universal method suitable for ensuring the long-term protection of building materials from water penetration in the conditions of its constant presence. The problem is solved partially by impregnating compositions like «Penetron», «Xypex», «Hydrotex» and others. They present waterproofing material of deep penetration for significant increase water resistance and prevention of capillary penetration of moisture through concrete. Their use allows you to protect the concrete from the effects of corrosive environments: acids, wastewater and groundwater, sea water. Processed concrete acquires resistance to carbonates, chlorides, sulfates, nitrates, etc. The use of penetron and others can improve the performance of waterproofness, strength, frost resistance of concrete. But their significant shortcomings that prevent the widespread use in the market of the Russian Federation is the high cost.

To provide long-term protection of building materials, it is proposed to treat the surfaces of porous building materials with a new sulfur-containing compound [4, 5]. The developed impregnating composition based on sulfur ensures the protection of building materials from weathering and corrosive environments for a long time. The composition is a sulfur-containing liquid, which due to its low viscosity during processing penetrates into the pore structure of the material to a depth of more than $1 \mathrm{~cm}$ and upon subsequent drying creates an insoluble protective coating in the pores of the material [6].

The technology of processing elements of structures and products is simple and accessible: like most paints and varnishes, they are applied by brush, pouring, spraying, dipping at any positive temperatures. The principal novelty of the proposed solution is that the hydrophobization is achieved by using a material of inorganic nature - sulfur. The presence of sulfur in the pores of building materials gives them water-repellent properties for a long time - unlike organic paints and varnishes. The originality of the approach is in the fact that at the impregnation stage a water-soluble substance is used and its sulfur molecules fall into the smallest pores of the material. At the drying stage this substance disintegrates and a water-insoluble (hydrophobic) layer of elemental sulfur is formed on the surface of the pores. The use of deep impregnation makes it possible, along with an increase in strength and frost resistance, to decrease water absorption, to significantly increase resistance to atmospheric factors, chemical resistance to acids, salt solutions, and petroleum products. The mineral nature of the coating ensures its durability, and the water repellency inherent in elemental sulfur prevents water from entering the pores of the material. The surfaces treated with the proposed composition acquire not only hydrophobic properties, but also pronounced bactericidal properties, as a result, the processes of decay and the formation of mold are prevented. The composition is not washed out under conditions of prolonged contact with water, it is effective as a primer composition before treatment with organosilicon compositions and solvent-based paints.

\section{MAIN PART}

\section{Research results}

To illustrate the possibilities of the proposed method of protection of building materials, the following experimental data obtained for materials tested in various conditions are proposed. Since the main focus of application is to protect building structures operating under conditions of constant exposure to moisture, we present the results of the study of the effect of impregnation of protective compound on the properties of various types of porous building materials.

It is known from $[7,8]$ that sulfur nanoparticles with an average size of $20 \mathrm{~nm}$ are deposited from polysulfide solutions, and sulfur nanoparticles observed in a probe microscope are shown in Fig. 1a. What sizes of sulfur particles are deposited on the walls of pores and capillary tracts of porous materials from polysulfide solutions? Particle sizing was carried out by examining the chip- 
a

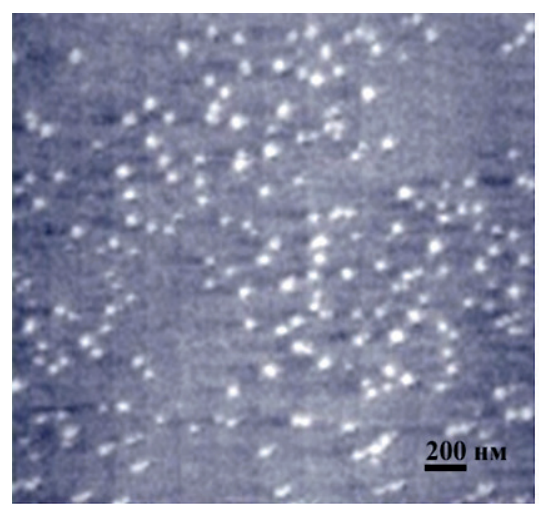

b

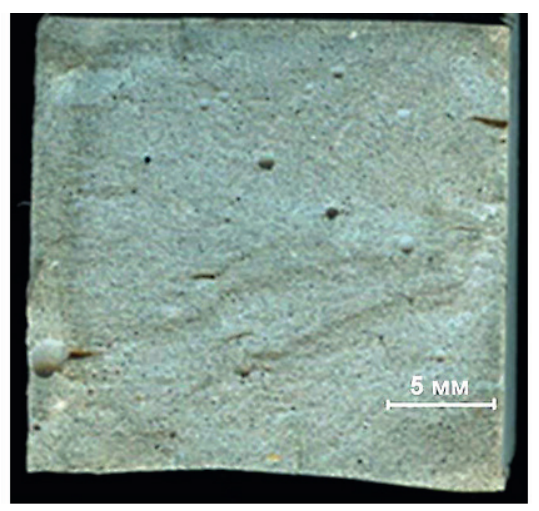

c

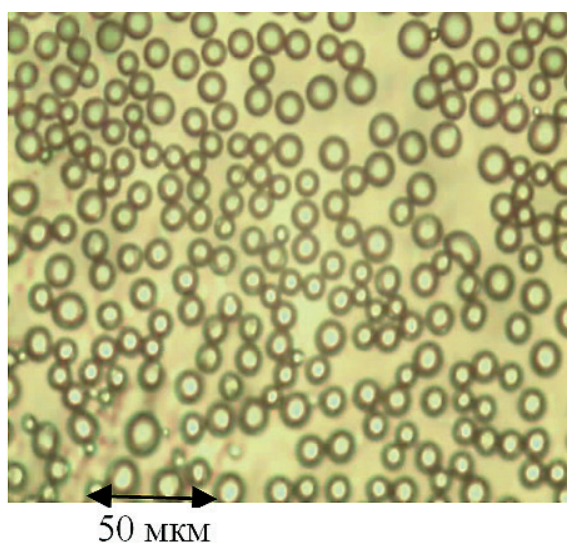

Fig. 1. Image of sulfur nanoparticles deposited on the surface from a polysulfide solution, obtained by means of: probe microscope (a); cleaving the concrete sample treated with polysulfide solution (b); sulfur particles on the surface of the glass, obtained by means of optical microscope (c)

ping of samples of fine-grained concrete $2 \times 2 \times 2 \mathrm{~cm}$ in size impregnated with a polysulfide solution for 4 hours at atmospheric pressure. In Fig. $1 \mathrm{~b}$ it can be seen that the areas of chips with a hydrophobic coating have a dark shade of color. Along the perimeter of the cleaved sample is clearly visible the area into which the impregnating compound has penetrated and, after drying, has formed a water-repellent layer.

In order to analyze the character of the particles in transmitted light, the distribution of the polysulfide solution on the glass after drying has been considered. Analysis of the surface of particles on glass under an optical microscope with a 100 -fold increase showed the presence on the surface of spherical formations resembling a collection of small spheres (Fig. 1c). The side of the square presented in Figure 1c is 500 microns. Thus, the polysulfide solution, as it dries, is crushed into many spheres, which are distributed almost evenly over the surface. In the similar way the formation of solid particles proceeds in the pores of materials. Sulfur nanoparticles are released from a polysulfide solution that has penetrated the smallest capillaries of a porous building material, are fixed on the surface of pores and give a hydrophobic effect.

Using a scanning multimicroscope, a 3-dimensional model was constructed and it was found out that as a result of processing porous material, a coating of sulfur nanoparticles is formed on the surface of pores and capillary tracts of the material (cross-sectional size is $20-$ $150 \mathrm{~nm}$, height is $2-10 \mathrm{~nm}$ ) (Fig. 2c), which prevents the penetration of water. These plaques of sulfur nanoparticles are clearly visible on the $3 \mathrm{D}$ image of the cleaved concrete obtained with scanning multimicroscope (Fig. 2a).
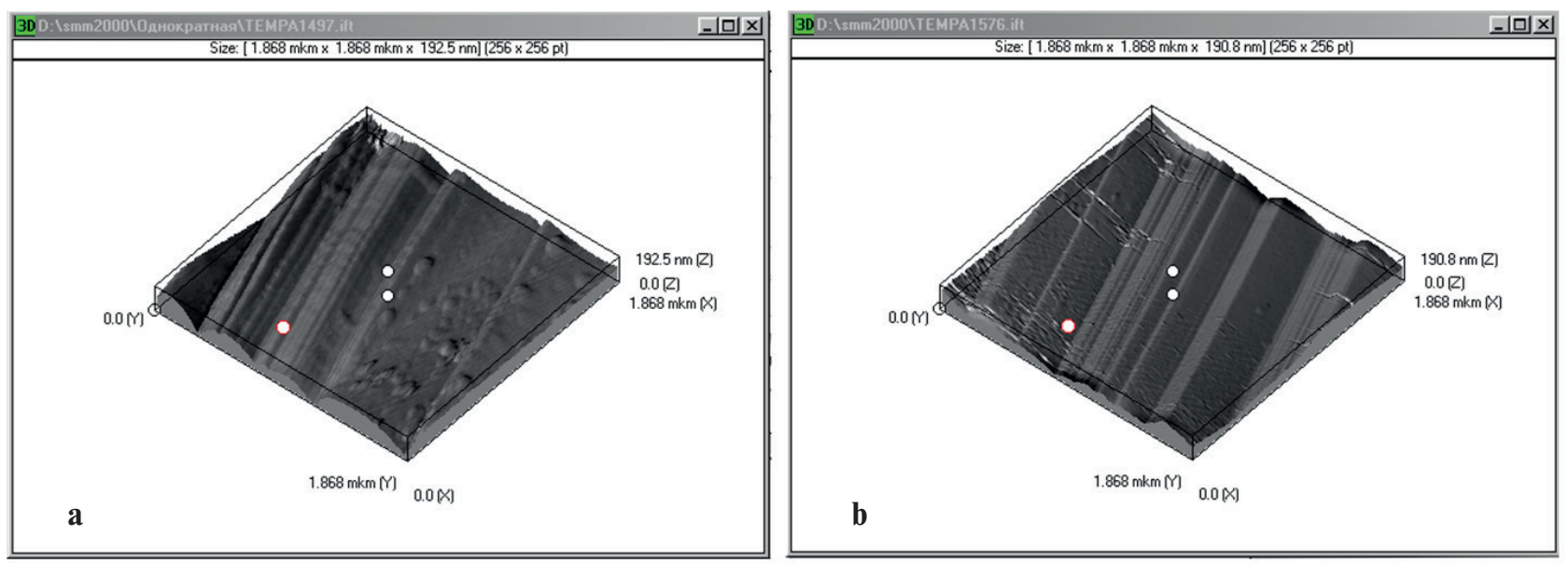

Fig. 2. Image of the cleaved sample of concrete: a) treated with a polysulfide solution; b) unprocessed 


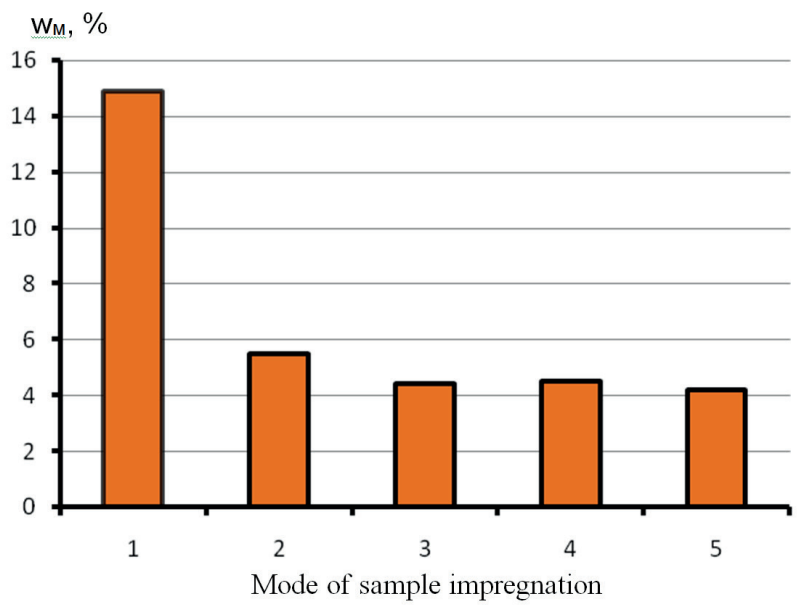

Fig. 3. The influence of the mode of impregnation with a solution of calcium polysulfide on water absorption by weight (wm) of ceramic brick samples: 1 - initial (non-impregnated); 2 - impregnated with a solution of a density of $1.18 \mathrm{~g} / \mathrm{cm}^{3} ; 3$ - soaked with a solution of a density of $1.25 \mathrm{~g} / \mathrm{cm}^{3} ; 4$ - impregnated with a brush in three passes with a solution of a density of $1.18 \mathrm{~g} / \mathrm{cm}^{3} ; 5$ - impregnated with a brush in three passes with a solution of a density of $1.25 \mathrm{~g} / \mathrm{cm}^{3}$

Figure 3 shows the dependence of water absorption by mass (wm) of ceramic brick on the mode of impregnation of samples. Usually water absorption by weight of non-impregnated ceramic brick is $14-16 \%$. The sample presented in Figure 3 has a value of w equal to $15.4 \%$. The water absorption of a sample of a ceramic brick impregnated with a polysulfide solution of a density of $1.18 \mathrm{~g} / \mathrm{cm}^{3}$ is equal to $5.4 \%$, thus, the value of this parameter decreased by 2.82 times. As a result of impregnation with a solution with a density of $1.25 \mathrm{~g} / \mathrm{cm}^{3}$, the water absorption of the sample decreased to a value of $4.5 \%$, that is, decreased by 3.5 times. Significant reduce of water absorption of the samples can be achieved due to application of solution with brush. When used for processing faces of solutions with a density of $1.18 \mathrm{~g} / \mathrm{cm}^{3}$ and $1.25 \mathrm{~g} / \mathrm{cm}^{3}$, the water absorption of the samples was $4.5 \%$ and $4.2 \%$, respectively.

The test results for ceramic brick samples impregnated with a polysulfide solution show that full immersion impregnation protects the wall product from water penetration. The effectiveness of protection depends on the density of the solution. The method of applying the solution with a brush also effectively protects the walls of ceramic bricks from water penetration.

Let us consider the possibilities of the method of protecting structures with polysulfide solutions on samples of fine-grained concrete with an initial water absorption by weight of $12.4 \%$. Figure 4 shows the test data for samples

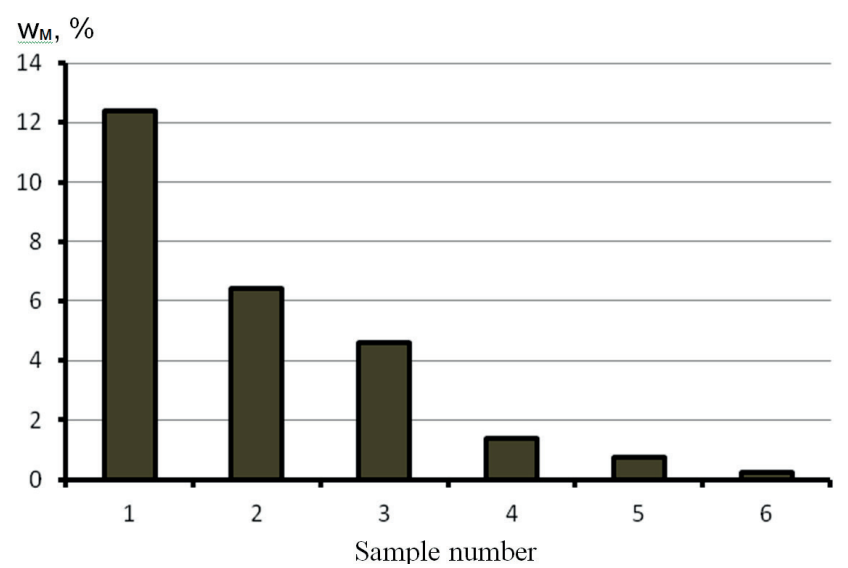

Fig. 4. Influence of the mode of impregnation with a solution of calcium polysulfide on water absorption by weight (wm) of samples of fine-grained cement concrete: 1 - water absorption of the non-impregnated sample; 2 - water absorption of the sample impregnated with immersion for 1 hour; 3 - water absorption of the sample impregnated with immersion for 4 hours; 4 - water absorption of the sample impregnated with immersion for 24 hours; 5 - impregnation in vacuum for 0.5 hours; 5 - vacuum impregnation for 4 hours

of fine-grained concrete obtained with different processing modes. In this case, impregnation for 1 hour provides a significant reduction in water absorption from value of $12.4 \%$ to $6.43 \%$, treatment for 4 hours reduces water absorption to value of $4.6 \%$. Impregnation for 24 hours allows to reduce water absorption to $1.4 \%$, which is a good result, since it corresponds to the level of water absorption of heavy concrete.

A further reduction in water absorption can be achieved by impregnating samples under vacuum, in this case impregnation for 0.5 hours ensures a decrease in water absorption of the sample to $0.75 \%$, and aging under vacuum for 4 hours to $0.25 \%$. The data shown in Fig. 4 demonstrate that the treatment of fine-grained concrete with an impregnating composition reduces its water absorption to a level corresponding to heavy concrete, which leads to increase in frost resistance, water resistance and durability of products and structures made of fine-grained concrete and allows expanding the area of its use in manufacturing road products and designs, as well as front wall cladding products.

The results of experiments to study the effect of impregnation with a polysulfide solution on the compressive strength of full-scale products (concrete paving slabs of the Wave type) are shown in the table. The tests were carried out at a temperature of $20^{\circ} \mathrm{C}$, atmospheric pressure, impregnation lasted 4 hours. The average strength of the first series (6 samples) of non-impregnated concrete tiles 
Table.

Compressive strength of concrete pavement slabs impregnated with calcium polysulfide solution

\begin{tabular}{|l|c|c|c|c|}
\hline \multirow{2}{*}{ Name indicators } & \multirow{2}{*}{$\begin{array}{c}\text { The untreated } \\
\text { sample }\end{array}$} & $\begin{array}{c}\text { Solution density } \\
\mathbf{1 . 1} \mathbf{g} / \mathbf{c m}^{3}\end{array}$ & $\begin{array}{c}\text { Solution density } \\
\mathbf{1 . 2 3} \mathbf{g} / \mathbf{c m}^{3}\end{array}$ & $\begin{array}{c}\text { Solution density } \\
\mathbf{g} / \mathbf{c m}^{3}\end{array}$ \\
\cline { 3 - 5 } & & 2 & 3 & 4 \\
\hline Tile Series Number & 1 & 478 & 496 & 482 \\
\hline $\begin{array}{l}\text { The strength of concrete slabs } \\
\text { in compression, kgf/cm } \\
\text { (GOST 10180-2012) }\end{array}$ & 465 & & & \\
\hline
\end{tabular}

in compression was $465 \mathrm{kgf} / \mathrm{cm}^{2}$. Processing the tiles of series No. 2 with a solution of a density of $1.1 \mathrm{~g} / \mathrm{cm}^{3}$ leads to an increase in strength up to $478 \mathrm{~kg} / \mathrm{cm}^{2}$. Processing samples of series No. 3 with a solution of a density of $1.23 \mathrm{~g} / \mathrm{cm}^{3}$ provided an increase in strength to values of $496 \mathrm{~kg} / \mathrm{cm}^{2}$. A further increase in the density of the impregnating solution is not advisable, since it does not increase the strength of the concrete product (series No. 4), since a high density of the solution equal to $1.28 \mathrm{~g} / \mathrm{cm}^{3}$ leads to an increase in the viscosity of the solution, and it does not penetrate into the smallest concrete capillaries that ultimately leads to a decrease in strength. Thus, the impregnation of concrete with a solution of a density of $1.23 \mathrm{~g} / \mathrm{cm}^{3}$ leads to a compaction of its structure, which is manifested in an increase in the compressive strength of concrete tiles by $3-7 \%$.

\section{CONCLUSION}

Based on the above results, we can make the following conclusions:

1. The impregnation of porous building materials with polysulfide solutions creates the conditions for their penetration into the thinnest capillaries and deposition of crystallizable particles on the surface of pores in the form of sulfur nanoparticles, thereby ensuring a hydrophobic effect;

2. The proposed method of protection of building materials is universal, can be used for concrete products and structures, ceramic bricks, aerated concrete and other porous materials, processing can be carried out using a brush, dipping, spraying at room temperature similar to the technology of using other paints and varnishes, protection can be adjusted by the duration of the impregnation and the number of repetitions of the process [9-11].

3. The practical importance of the proposed method of protection of concrete and reinforced concrete structures and products exposed to the direct impact of groundwater is that water absorption by concrete mass can be achieved within 1-3\% and the waterproofing grade W8-W10 at which water ceases to be filtered through concrete surface.

4. The method considered in this article is promising for the protection of external surfaces of masonry facades of buildings from any small-piece wall products, as well as wall and road concrete products. In addition, the method can be used to maintain the operational reliability of external walls and foundations of existing buildings and structures that require major repairs.

\section{ВВЕДЕНИЕ}

3 адача создания надежных защитных покрытий, повышающих механические характеристики бетонных строительных конструкций (свай, мостов, арок перекрытий, тоннелей, лотков, водопропускных труб, колодцев, тротуарных и дорожных плит, бордюрных камней и др.), эксплуатирующихся в условиях воздействия атмосферных факторов и грунтовых вод, актуальна. Увеличение долговечности и надежности дорожных конструкций, эксплуатирующихся в условиях воздействия механических и атмосферных факторов, обычно достигается применением различного рода модифицирования бетона [1], применения защитных пропиточных составов [2, 3]. Самым главным недостатком покрытий является недолговечность компонентов самих защитных покрытий. Во всех зданиях и сооружениях есть элементы конструкций, подверженные интенсивному воздействию влаги и грунтовых вод: фундаментные блоки, 
подушки и плиты, сваи; цокольные и подоконные участки стен, парапеты, выступающие элементы фасадов (карнизы, пояски); плиты покрытия; лотки, колодцы, бордюрные камни, тротуарная плитка; арки, водопропускные трубы, элементы мостов и др. Для их защиты нельзя обойтись образованием тонкой пленки защитного покрытия на поверхности материала, а требуется применение составов, которые бы глубоко проникали глубоко внутрь материала и предохраняли его от проникновения воды при ее постоянном воздействии. В этих случаях используют различные связующие (полимерные, кремнийорганические, жидкое стекло, расплав серы и пр.). Каждому из перечисленных материалов присущи недостатки. Например, органические и кремнийорганические соединения, несмотря на высокую эффективность в начале срока эксплуатации, постепенно претерпевают деструкцию и теряют свои защитные функции. Таким образом, в настоящее время отсутствует универсальный метод, пригодный для обеспечения долговременной защиты строительных материалов от проникновения воды в условиях ее постоянного присутствия. Отчасти проблема решается пропиточными составами типа «Пенетрон», «Ксайпекс», «Гидротекс» и другие, они представляют собой гидроизоляционный материал глубокого проникновения для значительного увеличения водонепроницаемости и предотвращения капиллярного проникновения влаги через бетон. Их применение позволяет защитить бетон от воздействия агрессивных сред: кислот, сточных и грунтовых вод, морской воды. Обработанный бетон приобретает стойкость к воздействию карбонатов, хлоридов, сульфатов, нитратов и пр. Применение пенетрона и др. позволяет повысить показатели водонепроницаемости, прочности, морозостойкости бетона. Но их существенными недостатками, препятствующими широкому использованию на рынке РФ, является высокая стоимость.

В качестве средства долговременной защиты строительных материалов предлагается обработка поверхностей пористых строительных материалов новым серосодержащим составом [4, 5]. Разработанный пропиточный состав на основе серы обеспечивает защиту строительных материалов от атмосферных воздействий и агрессивных сред в течение длительного времени. Состав представляет собой серосодержащую жидкость, которая благодаря низкой вязкости при обработке проникает в поровую структуру материала на глубину более 1 см и при последующем высыхании создает в порах материала нерастворимое защитное покрытие [6].

Технология обработки элементов конструкций и изделий проста и доступна: как и большинство лакокрасочных материалов, они наносятся кистью, наливом, распылением, погружением при любых положительных температурах. Принципиальная новизна предлагаемого решения заключается в том, что гидрофобизация достигается применением материала неорганической природы - серы. Наличие серы в порах строительных материалов придает им водоотталкивающие свойства на длительное время в отличие от органических лакокрасочных материалов. Оригинальность подхода заключается в том, что на стадии пропитки используется растворимое в воде вещество, в составе которого молекулы серы попадают в мельчайшие поры материала. На этапе сушки это вещество распадается и на поверхности пор образуется нерастворимый в воде (гидрофобный) слой элементной серы. Применение глубокой пропитки позволяет наряду с повышением прочности и морозостойкости, уменьшением водопоглощения существенно повысить стойкость к атмосферным факторам, химическую стойкость к кислотам, солевым растворам, нефтепродуктам. Минеральная природа покрытия обеспечивает его долговечность, а присущие элементной сере водоотталкивающие свойства предотвращают доступ воды в поры материала. Поверхности, обработанные предлагаемым составом, приобретают не только гидрофобные свойства, но также и ярко выраженные бактерицидные свойства, в результате предотвращаются процессы гниения и образования плесени. Состав не вымывается в условиях длительного контакта с водой, эффективен в качестве грунтовочного состава перед обработкой кремнийорганическими композициями и красками на основе растворителей.

\section{ОСНОВНАЯ ЧАСТЬ}

\section{Результаты исследований}

Для иллюстрации возможностей предлагаемого метода защиты строительных материалов предлагаются следующие экспериментальные данные, полученные для материалов, испытанных в различных условиях. Так как основным направлением применения предполагается защита строительных конструкций, эксплуатируемых в условиях постоянного воздействия влаги, приводим результаты исследования влияния пропитки защитным составом на свойства различных видов пористых строительных материалов.

Из работ [7, 8] известно, что из полисульфидных растворов осаждаются наночастицы серы средним размером 20 нм, на рис.1а изображены наночастицы серы, наблюдаемые в зондовом микроскопе. Каких же размеров частицы серы осаждаются на стенках пор и капиллярных трактов пористых материалов из полисульфидных растворов? Определение разме- 
a

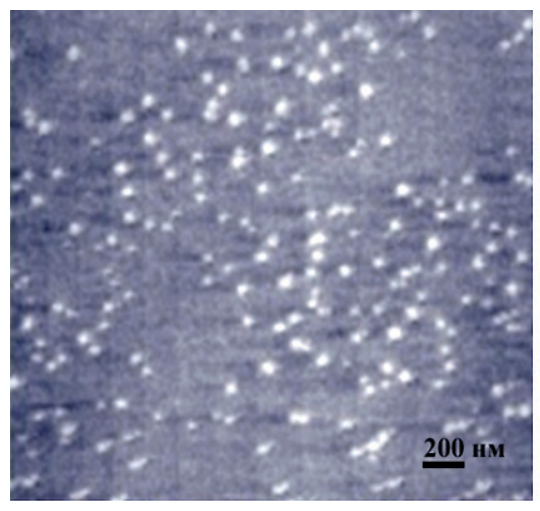

б

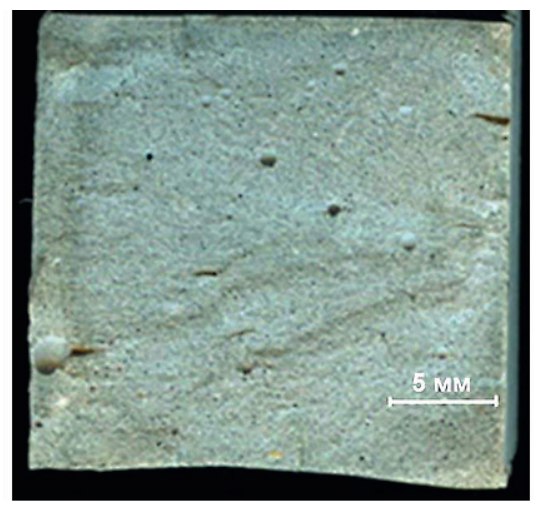

B

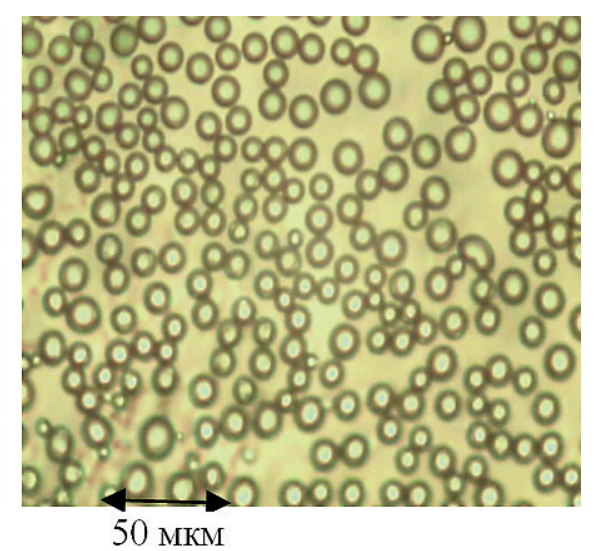

Рис. 1. а - Изображение наночастиц серы из полисульфидного раствора, полученное с помощью зондового микроскопа; б - изображение скола бетона образца, обработанного полисульфидным раствором; в - изображение наночастиц серы на поверхности скола бетона, полученное с помощыю сканирующего мультимикроскопа

ров частиц проводилось путем исследования сколов образцов мелкозернистого бетона размером $2 \times 2 \times 2$ см, пропитанных полисульфидным раствором в течение 4 часов при атмосферном давлении. На рис.1б видно, что области сколов, имеющие гидрофобное покрытие, имеют темный оттенок цвета. По периметру скола образца отчетливо видна область, в которую проник пропиточный состав и после высыхания образовал водоотталкивающий слой.

Для того чтобы проанализировать в проходящем свете характер частиц, было рассмотрено распределение полисульфидного раствора на стекле после высыхания. Анализ поверхности частиц на стекле под оптическим микроскопом со 100-кратным увеличением показал присутствие на поверхности сфери- ческих образований, напоминающих совокупность маленьких сфер (рис. 1в). Сторона квадрата, представленного на рис.1в, равна 400 микрон. Таким образом, полисульфидный раствор по мере высыхания дробится на множество сфер, которые распределены практически равномерно по поверхности. Аналогично происходит и формирование твердых частиц и в порах материалов. Из полисульфидного раствора, проникшего в мельчайшие капилляры пористого строительного материала, в процессе высыхания выделяются наночастицы серы, которые закрепляются на поверхности пор и дают гидрофобный эффект.

С помощью сканирующего мультимикроскопа построена 3-х мерная модель и установлено, что в результате обработки пористого материала на по-
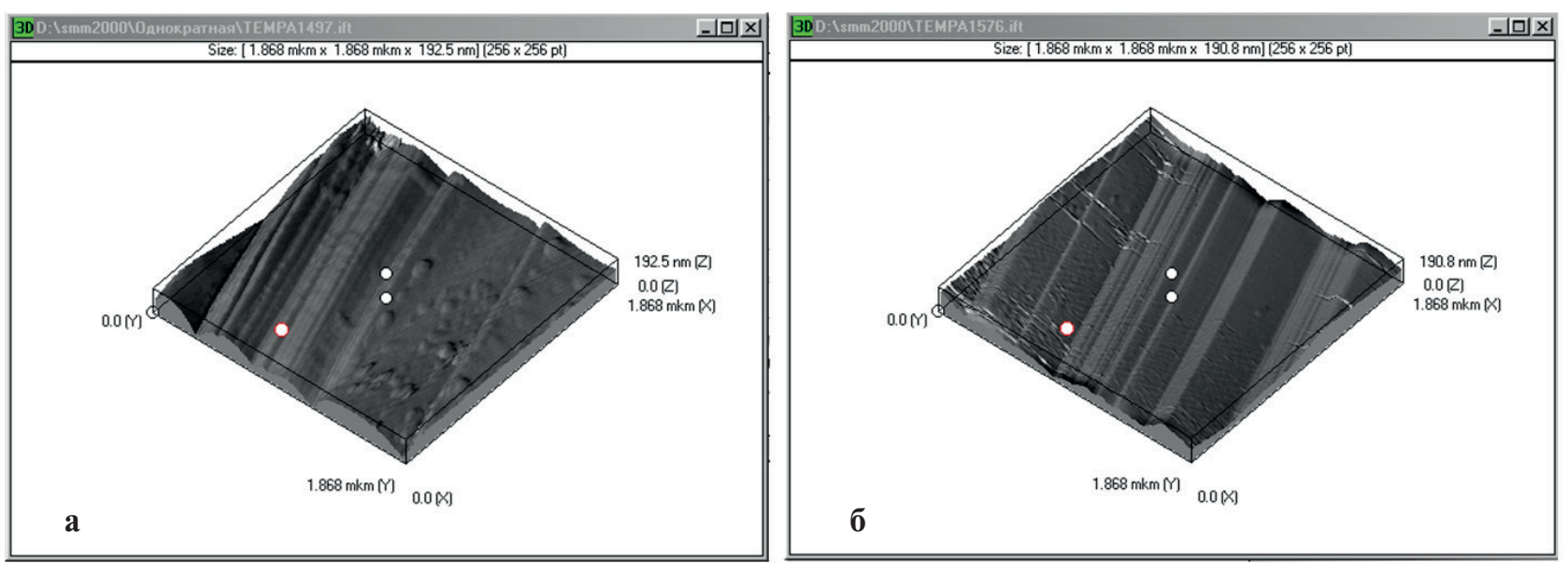

Рис. 2. Изображение скола образца бетона: а) обработанного полисульфидным раствором; б) необработанного 


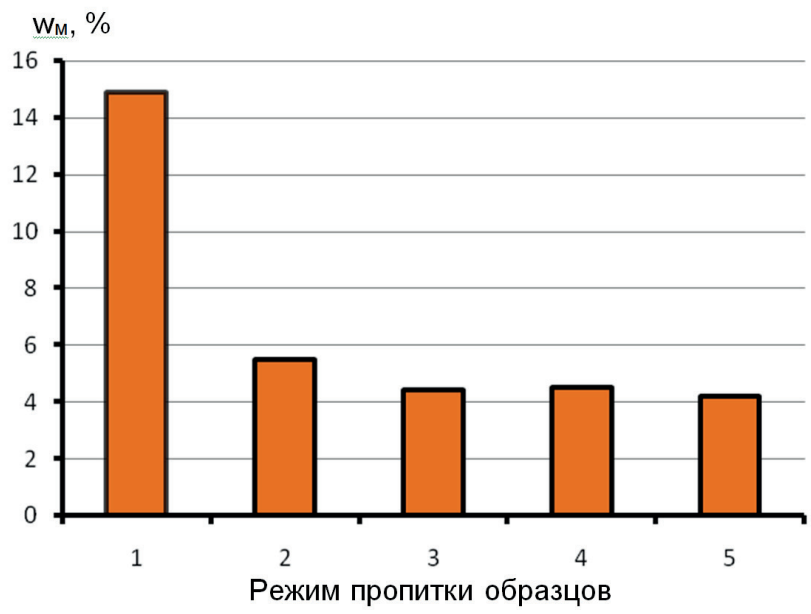

Рис. 3. Влияние режима пропитки раствором полисульфида кальция на водопоглощение по массе (шм) образцов керамического кирпича: 1 - исходный (непропитанный); 2 - пропитанный раствором

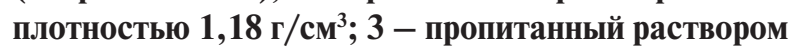

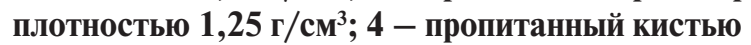

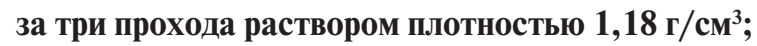
5 - пропитанный кистью за три прохода раствором

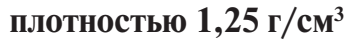

верхности пор и капиллярных трактов материала образуется покрытие из наночастиц серы (поперечный размер - 20-150 нм, высота - 2-10 нм) (рис. 2в), которое препятствует проникновению воды. Эти бляшки из наночастиц серы отчетливо видны на объемном изображении скола бетона, полученного с помощью сканирующего мультимикроскопа (рис.2а).

На рис. 3 приведена зависимость водопоглощения по массе (wм) керамического кирпича от режима пропитки образцов. Обычно водопоглощение по массе непропитанного керамического кирпича составляет 14-16\%. Образец, представленный на рис. 3 , имеет значение w равное $15,4 \%$. Водопоглощение образца керамического кирпича, пропитанного раствором полисульфида плотностью

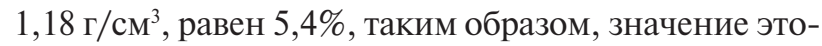
го параметра уменьшилось в 2,82 раза. В результате пропитки раствором плотностью 1,25 г/ $\mathrm{cm}^{3}$ водопоглощение образца снизилось до значения 4,5\%, то есть уменьшилось в 3,5 раза.

Значительно снизить водопоглощение образцов позволяет нанесение раствора кистью. При использовании для обработки граней растворов плотностью

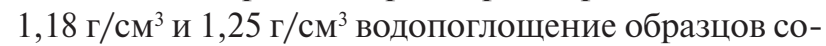
ставило $4,5 \%$ и $4,2 \%$ соответственно.

Результаты испытаний для образцов керамического кирпича, пропитанных полисульфидным раствором, показывают, что пропитка полным
$\mathrm{Wm}_{\mathrm{m}}, \%$

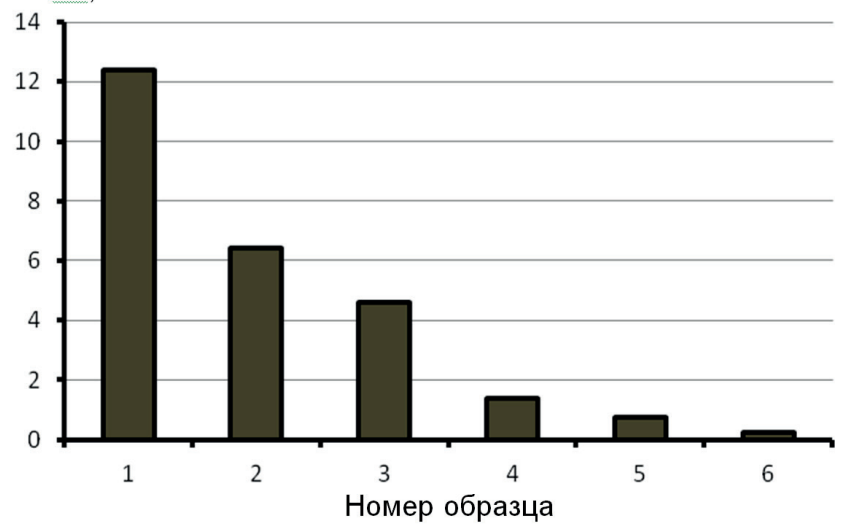

Рис. 4. Влияние режима пропитки раствором полисульфида кальция на водопоглощение по массе (wм) образцов мелкозернистого цементного бетона: 1 - водопоглощение непропитанного образца; 2 - водопоглощение образца, пропитанного погружением на 1 час; 3 - водопоглощение образца, пропитанного погружением на 4 часа; 4 - водопоглощение образца, пропитанного погружением на 24 часа; 5 - пропитка в вакууме в течение 0,5 часа; 5 - пропитка в вакууме в течение 4 часов

погружением хорошо защищает стеновое изделие от проникновения воды. Эффективность защиты зависит от плотности раствора. Способ нанесения раствора кистью также позволяет эффективно защищать стены из керамического кирпича от проникновения воды.

Рассмотрим возможности метода защиты конструкций полисульфидными растворами на образцах мелкозернистого бетона с исходным водопоглощением по массе 12,4\%. На рис. 4 приведены данные испытаний для образцов мелкозернистого бетона, полученные при различных режимах обработки. В этом случае пропитка в течение 1 часа обеспечивает существенное снижение водопоглощения со значения $12,4 \%$ до $6,43 \%$, обработка в течение 4 часов снижает водопоглощение до значения 4,6\%. Пропитка в течение 24 часов позволяет снизить водопоглощение до $1,4 \%$, что является хорошим результатом, так как соответствует уровню водопоглощения тяжелого бетона.

Дальнейшее снижение водопоглощения можно обеспечить при пропитке образцов под вакуумом, в этом случае пропитка в течение 0,5 часа обеспечивает снижение водопоглощения образца до $0,75 \%$, а выдержка под вакуумом в течение 4 часов - до 0,25\%. Данные, приведенные на рис.4, показывают, что обработка мелкозернистого бетона пропиточным составом позволяет снизить его водо- 
APPLICATION OF NANOTECHNOLOGIES AND NANOMATERIALS • ПРИMEHEHИE НАНОTEХНОЛОГИЙ И НАНОМАTEРИАЛОВ

Таблица

Прочность на сжатие бетонных тротуарных плиток, пропитанных раствором полисульфида кальция

\begin{tabular}{|c|c|c|c|c|}
\hline \multirow{2}{*}{$\begin{array}{c}\text { Наименование } \\
\text { показателей }\end{array}$} & \multirow{2}{*}{$\begin{array}{c}\text { Необработанный } \\
\text { образец }\end{array}$} & \multicolumn{3}{|c|}{ Плиты бетонные тротуарные «Волна» } \\
\hline & & $\begin{array}{c}\text { плотность раствора } \\
1,1 \text { г } / \mathrm{cm}^{3}\end{array}$ & \begin{tabular}{|c|} 
плотность раствора \\
1,23 г/см \\
\end{tabular} & $\begin{array}{c}\text { плотность раствора } \\
1,28 \text { г/ } / \mathrm{cm}^{3} \\
\end{array}$ \\
\hline Номер серии плиток & 1 & 2 & 3 & 4 \\
\hline 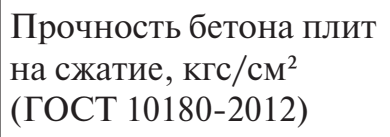 & 465 & 478 & 496 & 482 \\
\hline
\end{tabular}

поглощение до уровня, соответствующего тяжелому бетону, что приводит к повышению морозостойкости, водонепроницаемости и долговечности изделий и конструкций из мелкозернистого бетона и позволяет расширить область его использования при изготовлении дорожных изделий и конструкций, а также фасадных стеновых облицовочных изделий.

Результаты экспериментов по исследованию влияния пропитки полисульфидным раствором на прочность на сжатие натурных изделий (плитки бетонные тротуарные типа «Волна») приведены в табл. Испытания проводились при температуре $20^{\circ} \mathrm{C}$, атмосферном давлении, пропитка длилась 4 часа. Средняя прочность первой серии (6 образцов) непропитанных бетонных плиток на сжатие составила 465 кгс/см² . Обработка плиток серии № 2 раствором плотностью 1,1 г/см³ приводит к возрастанию прочности до 478 кг/см². Обработка образцов серии № 3

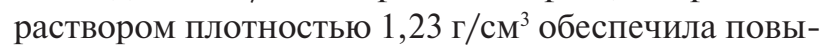
шение прочности до значений 496 кг/см². Дальнейшее увеличение плотности пропиточного раствора не целесообразно, так как не приводит к повышению прочности бетонного изделия (серия № 4), из-

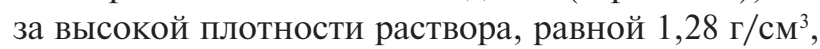
приводит к увеличению вязкости раствора, и он не проникает в самые мелкие капилляры бетона, что в конечном итоге приводит к снижению прочности. Таким образом, пропитка бетона раствором

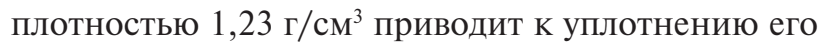
структуры, что проявляется в повышении прочности на сжатие бетонных плиток на 3-7\%.

\section{ЗАКЛЮЧЕНИЕ}

На основании приведенных результатов можно сделать следующие выводы:
1. При пропитке пористых строительных материалов полисульфидными растворами создаются условия их проникновения в самые тонкие капилляры и осаждения кристаллизующихся частиц на поверхности пор в виде наночастиц серы, тем самым обеспечивается гидрофобный эффект;

2. Предложенный метод защиты строительных материалов является универсальным, может быть использован для бетонных изделий и конструкций, керамического кирпича, газобетона и других пористых материалов, обработка может быть осуществлена с помощью кисти, погружением, распылением при комнатной температуре аналогично технологии применения других лакокрасочных материалов, уровень защиты может регулироваться длительностью пропитки и количеством повторений процесса обработки [9-11].

3. Практическое значение предлагаемого метода защиты бетонных и железобетонных конструкций и изделий, подвергающихся прямому воздействию подземных вод, заключается в том, что можно добиться водопоглощения по массе бетона в пределах 1-3 \% и марки по водонепроницаемости W8-W10, при которых вода перестает фильтроваться через бетонную поверхность.

4. Рассмотренный в данной статье метод перспективен для защиты внешних поверхностей кладки фасадов зданий из любых мелкоштучных стеновых изделий, а также стеновых и дорожных изделий из бетона. Кроме того, метод может быть использован для поддержания эксплуатационной надежности наружных стен и фундаментов существующих зданий и сооружений, требующих капитального ремонта. 


\section{REFERENCES}

1. Bazhenov Yu.M., Kalashnikov V.I., Demyanova V.S. Modified high quality concretes. Moscow, Publishing house ASV, 2006, 368 p. (In Russian).

2. Ramachandran V., Feldman R., Baudouin J. Concrete Science. Physico-chemical concrete science. Per. from English Ed. Ratinova V.B. Moscow, Stroiizdat, 1986, 278 p. (In Russian).

3. Pokrovsky N.S. Impregnating waterproofing concrete. Moscow, Energy, 1964, 112 p. (In Russian).

4. Musavirov R.S., Massalimov I.A., Babkov V.V., Chuykin A.E., Balobanov M.A., Sharabyrov M.V Impregnating water-repellent compositions based on water-soluble sulfur. Construction materials. 2003. № 10. p. 25-27. (In Russian).

5. Massalimov I.A., Yanakhmetov M.R., Chuykin A.E., Mustafin A.G. Protection of Building Constructions with Sulfur Impregnating Solution. Study of Civil Engineering and Constructions with Sulfur Impregnating Solution 2013. Vol. 2, Issue 2, p. $19-24$.

6. Massalimov I.A., Chuikin A.E., Yanakhmetov M.R., Khusainov A.N., Mustafin A.G. The method of processing construction materials with polysulfide solutions. Eurasian patent number № 024383. 2014.

7. Massalimov I.A., Shaynurova A.R., Khusainov A.N., Mustafin A.G. Production of sulfur nanoparticles from an aqueous solution of potassium polysulfide. Journal of Applied Chemistry, 2012, Vol. 85, № 11, p. 1944-1949. (In Russian).

8. Massalimov I.A., Khusainov A.N., Zainitdinova R.M., Musavirova L.R., Zaripova L.R., Mustafin A.G. Chemical sedimentation of sulfur nanoparticles. Journal of Applied Chemistry. 2014, Vol. 87, № 6, p. 705-713. (In Russian).

9. Massalimov I.A., Yanakhmetov M.R., Chuykin A.E., Massalimov B.I., Urakaev F.H., Uralbekov B.M., Burkitbaev M.M. Hydrophobization of dense and fine concrete by polysulfide solutions. Nanotehnologii v stroitel'stve = Nanotechnologies in Construction. 2016, Vol. 8, no. 5, pp. 85-99. DOI: dx.doi.org/10.15828/2075-85452016-8-5-85-99. (In Russian).

10. Chuikin A.E., Babkov V.V., Massalimov I.A. Modification of cement concrete with impregnating sulfur-containing solutions. Construction Materials Journal. 2016, № 10, p. 72-75. (In Russian).

11. Massalimov I.A., Chuykin A.E., Massalimov B.I., Urakaev F.H., Uralbekov B.M., Burkitbaev M.M. Improvement of operational properties of shell limestone building materials by polysulfide solution impregnation. Nanotehnologii v stroitel'stve = Nanotechnologies in Construction. 2017, Vol. 9, no. 3, pp. 66-80. DOI: dx.doi. org/10.15828/2075-8545-2017-9-3-66-80. (In Russian).

\section{СПИСОК ЛИТЕРАТУРЫ}

1. Баженов Ю.М., Калашников В.И., Демьянова В.С. Модифицированные высококачественные бетоны. - М.: АСВ, 2006. $-368 \mathrm{c}$.

2. Рамачандран В., Фельдман Р., Бодуэн Дж. Наука о бетоне. Физико- химическое бетоноведение. Пер. с англ. Под ред. Ратинова В.Б. - М.: Стройиздат, 1986. - 278 с.

3. Покровский Н.С. Пропиточная гидроизоляция бетона. - М.: Энергия, 1964. - 112 с.

4. Пропиточные гидрофобизирующие композиции на основе водорастворимой серы // Мусавиров Р.С., Массалимов И.А., Бабков В.В., Чуйкин А.Е., Балобанов М.А., Шарабыров М.В // Строительные материалы. - 2003. - № 10. C. 25-27.

5. Protection of Building Constructions with Sulfur Impregnating Solution/ Massalimov I.A., Yanakhmetov M.R., Chuykin A.E., Mustafin A.G/ Study of Civil Engineering and Architecture (SCEA) Volume 2, Issue 2, June 2013, p. 19-24.

6. Массалимов И.А., Чуйкин А.Е., Янахметов М.Р., Хусаинов А.Н., Мустафин А.Г. Способ обработки строительных материалов полисульфидными растворами: Евразийский патент № 024383. - приоритет от 26.04.2014.

7. Массалимов И.А., Шайнурова А.Р., Хусаинов А.Н., Мустафин А.Г. Получение наночастиц серы из водного раствора полисульфида калия // Журнал прикладной химии. - 2012. - Т. 85, № 11. - С. 1944-1949. - DOI: 10.1134/ S1070427212120075.

8. Массалимов И.А., Хусаинов А.Н., Зайнитдинова Р.М., Мусавирова Л.Р., Зарипова Л.Р., Мустафин А.Г. Химическое осаждение наночастиц серы // Журнал прикладной химии. - 2014. - T.87, № 6. - C. 705-713. - DOI: 10.1134/ S1070427214060068.

9. Массалимов И.А., Янахметов М.Р., Чуйкин А.Е., Массалимов Б.И., Уракаев Ф.Х., Уралбеков Б.М., Буркитбаев М.М. Гидрофобизация плотного и мелкозернистого бетонов полисульфидными растворами // Нанотехнологии в строительстве. - 2016. - Том 8, № 5. - C. 85-99. - DOI: 10.15828/2075-8545-2016-8-5-85-99.

10. Чуйкин А.Е., Бабков В.В., Массалимов И.А. Модифицирование цементного бетона пропиточными серосодержащими растворами // Строительные материалы. - 2016. - № 10. - С. 72-75.

11. Массалимов И.А., Чуйкин А.Е., Массалимов Б.И., Уракаев Ф.Х., Уралбеков Б.М., Буркитбаев М.М. Улучшение эксплуатационных свойств строительных материалов из известняка ракушечника пропиткой полисульфидными растворами // Нанотехнологии в строительстве. - 2017. - Т. 9, № 3. - С. 66-80. - DOI: 10.15828/2075-8545-2017-9-3-66-80. 


\section{INFORMATION ABOUT THE AUTHORS}

Ismail A. Massalimov, professor of Bashkir State University (BashSU); Ufa, Bashkortostan Republic, Russia, ismail_mass@mail.ru;

Aleksandr E. Chuykin, docent, Ufa State Petroleum Technological University (USPTU), Ufa, Bashkortostan Republic, Russia, an2100@yandex.ru;

Burhan I. Massalimov, a graduate student, Physics Institute. P.N. Lebedev, Russian Academy of Sciences; Moscow, Russia; burhan@mephist.ru;

Bulat S. Akhmetshin, Assistant, Bashkir State University Ufa, Bashkortostan Republic, Russia; akhbulat@mail.ru;

Farit H. Urakaev, Senior Researcher, V.S. Sobolev Institute of Geology and Mineralogy of the Russian Academy Science; Russia, Novosibirsk, urakaev@igm.nsc.ru;

Muhambetkali M. Burkitbaev, Vice Rector, Al-Farabi Kazakh National University; Al-Farabi, Almaty, Kazakhstan; mukhambetkali.Burkitbayev@kaznu.kz

Akhat G. Mustafin, Head of Ufa Scientific Center, Ufa Bashkortostan Republic, Russia; agmustafin@gmail.com

\section{ИНФОРМАЦИЯ ОБ АВТОРАХ}

Масалимов Исмаил Александрович, профессор Башкирского государственного университета (БашГУ); Уфа, Республика Башкортостан, Россия, ismail_mass@mail.ru;

Чуйкин Александр Евгеньевич, доцент, Уфимский государственный нефтяной технический университет (УГНТУ), Уфа, Республика Башкортостан, Россия, an2100@yandex.ru;

Массалимов Бурхан Исмаилович, аспирант Физического института им. П.Н. Лебедева, Российская академия наук; Москва, Россия; burhan@mephist.ru;

Ахметшин Булат Салаватович, ассистент Башкирского государственного университета Уфа, Республика Башкортостан, Россия; akhbulat@mail.ru;

Уракаев Фарит Хисамутдинович, старший научный сотрудник, В.С. Институт геологии и минералогии им. С.Л. Соболева РАН; Россия, Новосибирск, urakaev@igm.nsc.ru;

Буркитбаев Мухамбеткали Мырзабаевич, проректор КазНУ им. Аль-Фараби; Аль-Фараби, Алматы, Казахстан; mukhambetkali.Burkitbayev@kaznu.kz

Мустафин Ахат Григорьевич, руководитель Уфимского научного центра, Уфа, Республика Башкортостан, Россия, agmustafin@gmail.com 